\title{
THE LAW CONCERNING FOREIGN RECEIVERS
}

In the early administration of law in this country, the states were regarded as foreign to each other in a sense much stricter than the prevailing one. The earlier conception of their relationship was the natural outgrowth of their jealousy toward each other and desire to maintain their autonomy. With the growth of business interests a different conception has been developing, which demands the application of similar rules for all without much regard for state lines. Our national bankruptcy law is one of the ripened fruits of a common country's experience. Before, Iocal creditors obtained undue advantage over outside creditors; now, the advantage or conditions of all creditors are equalized.

The need of overlooking state lines to serve the higher end of justice is clearly seen in administering the law of foreign receivers. In 1854, the Supreme Court of the United States decided that a judicial receiver "has no extra territorial power of official action; none which the court appointing him can confer, with authority to enable him to go into a foreign jurisdiction to take possession of the debtor's property; none zvhich can give him, upon the principle of comity', a privilege to stie in a foreign court or another jurisdiction, as the judgment creditor himself might have done, where his debtor may be answerable to the tribunal which the creditor may seek." 1 To that rule the highest ferleral court has always adhered. ${ }^{2}$

Though a foreign receiver by the federal rule is denied autthority to act in a foreign jurisdiction, an anxiliary receiver may be appointed who can act as effectively, perhaps more so, than a foreign receiver could act if he were judicially recognized. Consequently, he is often appointed by the federal courts. "It is true," says Justice Day, "that the auxiliary receiverships are generally conducted in harmony with the court of original jurisdiction, but such receivers are appointed with a view of vesting control of property rights in the court in whose jurisdiction they are located." ${ }^{3}$

1 Booth v. Clark, I7 How. 322, 338.

${ }^{2}$ Hale v. Allinson, I88 U. S. 56; Quincy, M. \& P. R. Co. v. Humphreys, 145 U. S. 82; Great Western Mining \& Manufacturing Co. v. Harris, 198 U. S. 56r; Fozuler v. Osgood, 72 C. C. A. 276, 141 Fed. 20

${ }^{3}$ Great Western Mining \& Manufacturing Co. v. Harris, Ig8 U. S. 561, 577; Foacler v. Osgood, I4I Fed. 20. 
The lower federal tribunals, on most occasions, have loyally followed the rule of the higher court. Again and again have the petitions of foreign receivers been denied. On most of these occasions, the denial has been founded on the superior rights of local creditors which, even admitting the rule of conity, are still everywhere recognized and enforced. ${ }^{4}$ Yet on some occasions the lower federal courts have applied the rule of comity, notwithstanding the deliverance in Booth $\%$. Clark. Thus, in Rogers $\approx$. Riley s the court, while maintaining the general rule that a receiver has no extra-territorial jurisdiction, held that it is limited by the exception arising out of comity, that whenever a receiver is appointed to collect the assets, pay the debts and wind up the affairs of a corporation, he may sue for that purpose in another jurisdiction, provided his bill shows that all the corporate clebts have been paid, so that there are no clomestic creditors requiring protection, and that there will be no infringement of the public policy of the state. The court seemingly acted on the belief or knowledge that "the rule of comity is not applied with the same strictness with which it is declared :" "

4 Zacher v. Fidelity Trust and Safety Vault Co., 45 C. C. A. 480; Edacard's ¿. National Windua Glass Jobbcrs' Associution, I.39 Fed. 795; Hazard z'. Durant, 19 Fed. 47I ; Brigham v. Luddington. I2 Blatchf. 237, 242; Olney v. Tanucr, 21 Blatchf. 540, affg. 10 Fed. IOI; Wilkinson z'. Culver, 23 Blatchf. 416; Chandler v. Boston Safe Dcposit Co. 72 Fed. 700, 701; Sands 2. Grecley, 88 Fed. 130, 45 C. C. A. 480 ; Hilliker z'. Halc, 54 C. C. A. 252 , 117 Fed. 220 , 225, citing many cases; Holmes a'. Sherzuood, 3 McCrary, 405. Contras Tully v. Herron, 44 Miss. 626, citing Kirkland v. Lowe, 33 Miss. 436; Farmers' and Merchants' Insurance Co. 2. Necdles, 52 Mo. $\mathrm{I}$; Moscby च. Burroa', 52 Tex. 396 (1880).

In Lezeis v. American Naval Stores' Co., Irg Fed. 39ז, 396, Selby, Cir. J. said: "The modern practice is to permit [the receiver] to bring suits on the ground of comity in all cases where such permission will not conflict with the rights of citizens or creditors in the state where the suit is brought. And the constant tendency of the courts is toward a more enlarged and liberal policy, - the recognition of the receiver's rixht to the possession of the property embraced by the decree appointing him, although situated without the jurisdiction of the court making the appointment. This tendency is so pronounced, and so well sustained by anthority, that it is probable that the doctrine ultimately to be established will give to receivers the same right of action in all the states of the Union with which they are invested in the jurisdiction in which they are appointed."

"80 Fed. 759; Lewis v. Clark, 129 Fed. 570; Lewis v. American Naral Stores Co., IIg Fed. 39r.

- Macfarlane, J., Robcrtson v. Staed, 135 Mo. 135, 138. 
saying to forcign chancery receivers that federal practice forbids the granting of their applications on the ground of comity, nevertheless, they will be granted in some cases, ancl it may be that favorable action is more frequent than is disclosed in the published reports. ${ }^{3}$

It is true that the lower federal courts have sometimes remarked that a foreign receiver cannot sue in a court of another juriscliction crcept by comity of the court zohose assistance he intokes," but have safely landed by denying the receiver's application for other reasons than lack of comity. ${ }^{\circ}$ Nor is the receiver's application strengthened by obtaining leave of the court to bring his application ; its final action is in no way narrowed by granting this preliminary request for it was "meaningless." 10

While denying to recognize foreign chancery receivers, the fecleral courts have never hesitated to apply a different rule to receivers who derived their authority from statute. In a recent case, Booth $\%$. Clark and its successors were invoked as precedents against permitting a corporation receiver appointed in Ncw York to sue a stockholder who lived in Minnesota. But the court, speaking through Justice Day', declared that those cases "held that a chancery receiver, having no other authority than that which would arise from his appointment as such, could not maintain an action in another juriscliction. In this case, the statute confers the right upon the receiver, as a quasi assignce,

7 Lcivis 2: Clark, 64 C. C. A. 138. 129 l:ed. 570. In Chandler v. Siddle, 3 Dill. 477, 479. Judge Miller said: "It is, perhaps. true, that where duly appointed and authorized, a receiver may ordinarily sue in another state. This power, when it exists, arises from comity in the alssence of special statute regulations, and it is in general, sulordinate to the rights of local creditors as respects property within the jurisdiction where such a suit is brought.

"Outside of the juriscliction which appoints him. a receiver is not ordinarily entitled to maintain suits except by comity; and this comity does not extend to aiding preferences sought to be acquired by: statutory assignments or other proceedings in invilum, to the detriment of other creditors whose interests are in the keeping of foreign or independent tribunals." Brown. Dist. J., Olncy r. Tanncr, Io Fed. I01, I04, citing Booth a'. Clark, I7 How. 322; Brigham v. Luddington. 12 Blatcl. 237. 242; Chandler a'. Siddlc, 3 Dill. 477 ; Willits $\approx$. If aite, 25 N. Y. 577, 587; Hoyt z. Thompson, 5 N. Y. 320; Runk r. St. Joltn, 29 Barb. 585; Batton r. I'alentinc. I Curt. 168: Hope Ifutual Instrunce Co. ¿. Taylor, 2 Rolot. 274. 284.

8 7uchex a. Fiddlity Trust and Sufoty Vault Co.. I06 Fed. 593. 595.

${ }^{\circ}$ See cases under Note 4.

10 Forder 2: Osgood, 72 C. C. A. 276. 
and representative of the creditors, and, as such, vested with the authority to maintain an action. In such cases, we think the receiver may sue in a foreign juriscliction." "11

Why should the United States Supreme Court be so reacly to extend the rule of comity to a statutory receiver while denving so uniformly the rule to a judicial receiver? Are the powers of the two so unlike as to justify this great clifference in treatment? It is said that the title to the property entrusted to a statutory receiver is vested in him, while the control over property exercised by a chancery receiver is limited by the appointing power. Yet the practical distinction between the authority of the two kinds has often been shadowy so far as disclosed in the history of the cases.

The federal remedy of appointing an auxiliary receiver, instead of permitting the foreign receiver to act, is strongly discountenanced by the highest court in New York whenever the foreign receiver can act, because his authority is cleclared to be more effective and his service less expensive. Says Justice lann, in describing the authority of a foreign receiver: "Subject to the superior rights of domestic creclitors, the plaintiff can recluce to possession all the property of the defenclant in this state, and can bring replevin for that purpose, or trover to recover clamages for conversion. Notes and accounts may be collected by the usual proceedings in our courts, which regard a foreign receiver as representing the original owner, and open their doors to him as they clo to a clomestic receiver." 12 On the occasion of this deliverance, as a foreign receiver possessed such ample authority, his application for the appointment of an auxiliary receiver was denied. ${ }^{13}$

Turning to the state courts, a striking change in practice is everywhere seen. While maintaining the cloctrine as firmly as the federal courts, that receivers have no lcgal rights beyond the states of their origin, in exercising comity the distinction between jutlicial and statutory receivers is practically ignored. The rule that prevails almost everywhere is thus stated by Chief Justice Beasley: "When there are no persons interested but the litigants in a foreign jurisdiction, and it becomes expedient in the progress of such suit that the-property of one of them, wherever it may be

${ }^{11}$ Bernlicimer v. Conzerse, 206 U. S. 516, 534: Relfe v. Rundlc, 103 U. S. 222, 226; Avery v. Boston Safe Dcposit and Trust Co.. 72 Fed. 700 . 12 Mabon z. Ongley Electric Co., 156 N. Y. 196. $20 \mathrm{r}$.

13 Ilid. 
situated, should be brought in and subjected to such proceeding, I can think of no objection against allowing such power to be exercised. It could not be exercised in a foreign jurisdiction to the disaclvantage of creditors resident there, because it is the policy of every government to retain in its own hands the property of a debtor until all domestic claims against it have been satisfied. But beyond this precaution, why should any restraint be put upon the foreign procedure?" 14

The courts, however, still maintain with nearly all their former vigor the superior rights of their own creditors, and their duty to uphold and defend their creditors' interests. Accordingly, while permitting a foreign receiver to stre, he cannot take away any of the property if needed to discharge the claims of home creditors. ${ }^{15}$ Thus, when the property of a foreign debtor has been garnisheed by a home creclitor, the courts of his state will protect him in holding it against a foreign receiver who wishes to take it away. ${ }^{10}$ Whenever, therefore, he is permitted to sue, he must submit to the limitations imposed by the foreign jurisdiction. ${ }^{17} \mathrm{He}$ can enforce his claim to the property of a nonresident debtor in his state only so far and in such a manner as the policy of the state permits. ${ }^{18}$ Nevertheless, persons who subscribe for stock in a builling and loan association are not entitled, should it dissolve, to retain its assets in the state where they live until all the claims are satisfied. ${ }^{19}$

14 Iurd v. City of Elizabeth, $4 \mathrm{I}$ N. J. Law, I, 3; Bidlack v. Mason, 26 N. J. Equity, 230; Sobcrnheinter v. Wheeler, 45 N. J. Eq. 614; Winans v. Gibbs \& Starrctt Mfg. Co., 48 Kan. 777; Boulvuare v. Davis, 90 Ala. 207; Metzncr v. Baucr, 98 Ind. 427 ; Catlin v. Wilcox Silver Plate Co., 23 Ind. 477, 479; Pond v. Cookc, 45 Conn. 126; Hunt v. Columbian Insurance Co., 55 Me. 297, 298; Runk v. St. John, 29 Barb. 585; Peterscn v. Chemical Bank, 32 N. Y. 1, 43; Mabon v. Ongley Electric Co., 156 N. Y. 196, 201, and cases cited; Graydon v. Church, 7 Mich. 36; Comstock v. Frcderickson, 5I Minn. 350; Scrcomb v. Collin, I28 Ill. 556; Swing v. Bentley \& Geravig Furniture Co., 45 W. Va. 283; Bagby v. Atlantic, Miss. \& Ohio R., $86 \mathrm{~Pa}$. 291 ; Cogill v. Woolridge, 8 Bax. 580; Merchants' National Bank v. McLcod, 38 Ohio St. 174; Hoyt v. Thompson, 5 N. Y. 320 ; S. C. I9 N. Y. 207; Willits v. Waite, 25 N. Y. 577, 584; Protection and Lombard Bank v. Thorp, 6 Cow. 46.

${ }^{15}$ Humphreys v. Hopkins, 81 Cal. 55I ; Lackmann v. Supreme Council of Order of Chosen Friends, 142 Cal. 22; Catlin v. Wilcox Silver Plate Co., 123 Ind. 477.

16 Ward \%. Pacific Mutual Jife Insurance Co.. r35 Cal. 235.

17 Zacher v. Fidelity Trust and Safety Vault Co., 106 Fed. 593, 595.

18 Ibid.

${ }^{10}$ Werdon i: Granite State Provident Association. Ion Ky. 504; Smith 
With respect to real estate, "an order appointing a receiver of realty has no extra-territorial operation, and cannot affect the title to real property which is located beyond the jurisdiction of the court by which the order was made." 20 Consequently, the home court cannot make certificates, issued by a receiver in obedience to its order, a lien on real estate beyond its jurisdiction. ${ }^{21}$ Still less authority has he to maintain an action in the state of his appointment to contest the title of purchasers under execution to real property in the state where it is situated. ${ }^{22}$ And doubtless the rule is without qualification that home creditors may hold the land of their foreign debtor by attachment or other proper proceeding against a foreign receiver, though perhaps not a foreign creditor. ${ }^{23}$ But a foreign receiver may foreclose a mortgage held by his debtor in another state, or enforce the right of redemption thereto. ${ }^{24}$ And a foreign receiver may sue on a bond and mortgage transferred by the court to him as successor of another receiver to whom the obligation was executed.. ${ }^{23}$

With respect to partnership property, a foreign receiver may take charge of it, but, as this is a mere substitution of parties, the receiver has no greater rights in such property than had the partners themselves. ${ }^{26} \mathrm{He}$ can indeed maintain an action for the benefit of a defrauded partner to set aside the fraudulent sale of partnership property effected by the other. ${ }^{27}$ But he cannot remove the funds of the partnership out of the state to the detriment of resident creditors. ${ }^{28}$

v. Taggart, 30 C. C. A. 363,87 Fed. 94 ; Maynard v. Granite Statc Provident Association, 34 C. C. A. 438, 92 Fed. 435; Irwin v. Granitc State Provident Association, 56 N. J. Eq. 244.

20 Schindelholz v. Cullum, 55 Fed. $885,889$.

${ }^{21}$ Pool v. Farmers' Loan and Trust Co., 7 Tex. Civ. App. 334.

22 Simpkins v. Smith and Parmclee Gold Co., 50 How. Pr. 56.

23 Moseby v. Burrow, 52 Tex. 396.

24 Graydon v. Church, 7 Mich. 36; Weller v. J. B. Pace Tobacco Co., 2 N. Y. Supp. 292; Lewis v. Clark, 64 C. C. A. 138, 129 Fed. 570; Boulware v. Davis, 90 Ala. 270. In the Graydon Case, the court remarked that the receiver did not sue strictly in his official character, but as an assignee holding the legal interest in the property by virtue of the debtor's assignment.

25 Iglehart v. Bicrce, 36 I1l. 133.

${ }^{28}$ Ogden v. Warren, $36 \mathrm{Neb}$. 715.

${ }^{27}$ Sobcrnheimer $v$. Whecler, 45 N. J. Eq. 614.

${ }^{28}$ Grogat! v. Egbcrt, 44 W. Va. 75. See Sobcrnheimer v. Wheeler, 45 N. J. Eq. 614. Nor will the removal be permitted as against the bona fide claims of the separate creditors of the members of the firm, unless he 
Even the superior rights of a forcign creditor who has property of his debtor within his jurisdiction will prevail where the title of the foreign assignor or receiver is acquired by virtue of a voluntary conveyance or transfer. In such cases, says Justtice Vann, his title "is sustained against all, even including domestic creditors." ${ }^{29}$ And the same rule has recently been cleclared in New Hampshire. ${ }^{30}$ But this rule is limited to voluntary transfers and does not cover those made by act of law. ${ }^{31}$

The reason for this distinction between voluntary and involuntary transfers, says Chief Justice Fuller, "is that a voluntary transfer, if valid where made, ought generally to be valid everywhere, being the exercise of the personal right of the owner to dispose of his own, while an assignment by operation of law has no legal operation out of the state in which the law was passed." 32 But an assignment which, though voluntarily made, works a distribution of the assignor's effects by statute is not a voluntary conveyance in the sense above described..33 Says Chief Justice Andrews: "The right of an insolvent or bankrupt to initiate voluntary proceedings in bankruptcy is a common feature in bankrupt laws, but that fact does not make the assignment voluntary, so as to give extra-territorial operation to the proceedings." ${ }^{34}$ For the same reason, the acceptance by a corporation of a bank charter whereby, if becoming insolvent, all its property is to vest forthwith in a receiver and be distributed by him in a prescribed manner, does not give to the transfer thus effected the character of a voluntary conveyance. ${ }^{3.5}$

Again, if a receiver has acquired title to the property entrusted to him in the state of his appointment, his title thereto is

first shows that the firm is insolvent and that the funds are necessary to satisfy the demands against it. Grogan Case, 44 W. Va. 75.

${ }^{29}$ Mabon v. Ongley Electric Co., 156 N. Y. 196, 201. See Willits v. Waite, 25 N. Y. 577, 584; Edmunds v. National Window Glass Jobbers" Association, I39 Fed. 795.

${ }^{3 n}$ Roberts v. Norcross, 69 N. H. 533.

31.Ibid: Carbee v. Mason, 64 N. H. Io.

${ }^{32}$ Cole a. Cunningham, 133 U. S. I07, 129: Roberts w. Norcross, 69 N. H. 533, 535, citing Barnctt 2. Kinncy, I47 U. S. 476, 481 ; Frank v. Bobbitt, 155 Mass. I12; Sazyyer v. Levy, 162 Mass. 190.

${ }^{33}$ Zipcey v. Thompson, 67 Mass. 243; Picrce 2 . O'Bricn, I29 Mass. 314; Joluson v. Parker, 4 Bush (Ky.) I49; Barth v. Backus, 140 N. Y. 230; Upton v. Hubbard, BR Conn. BGD.

34 Barth i'. Backus, 140 N. Y. 230. Sce Sccurity Trust Co. z' Dodd, Mead \& Co., 173 U. S. 624.

${ }^{35}$ Willits $v$. Waite, 25 N. Y. 577. 
not lost by sending it into another state. ${ }^{30}$ A creditor living there cannot take it from the receiver of an insolvent's estate to discharge the insolvent's indebtedness. The courts everywhere, it is believed, respect and preserve the receiver's title to his property held under these conditions. Much stronger is the reason for the rule if the property thus transported by the receiver in fulfillment of a contract, for example, has been purchased with other means belonging to the insolvent's estate. ${ }^{37}$ Still stronger is the reason for permitting a receiver to recover property which has been fraudulently or feloniously teceived from the jurisdiction of his appointment into another state $^{38}$ or to recover property which he has sent into another state to be sold. ${ }^{39}$

Will a foreign receiver be permitted to recover the property belonging to his assignor as against a creditor who may appear from the state where the debtor lived or from some other state? Of course, a creditor living in the foreign state would, by all the authorities, have a clear preference to the property, but the courts have divided on the other question. Strong anthorities may be ranged on either side. Those who favor the foreign creditor regard his rights to the property of the foreign debtor much in the same way as they regard the rights of a home creditor thereto in all attachment proceedings. Says the New York Court of Appeals: "Once properly in court and accepted as a suitor, neither the law, nor court administering the law, will admit any distinction between the citizen of its own state and that of another. Before the law and in its tribunals, there can be no preference of one over the other." 40

${ }^{36}$ Chicago, Miluaukie \& St. Paul R. Co. v. Keokuk Northern Line Packet Co., 108 Ill. 317; Robcrtson v. Staed, 135 Mo. I35; Merchants National Bank v. Pennsylvania Steel Co., 57 N. J. Law, 336; Woodhull v. Farmers' Trust Co., II N. Dak. 157; Merchants' National Bank v. McLeod, 38 Ohio St. 174; Cagill v. Woolridge, 8 Bax. 212; Upton v. Hubbards 28 Conn. 274. Contra: Humplircys v. Hopkins, 81 Cal. 557.

${ }^{37}$ Pond v. Cooke, 45 Conn. I26.

${ }^{38} \mathrm{McAlpin} v$. Jones, ro La. Assn. 552.

${ }^{39}$ Cagill $v$. Woolridgc, $8 \mathrm{Bax} .580$.

${ }^{40}$ Hibernia National Bank v. Lacombe, 84 N. Y. 367, 385; Warner v. Jaffray, 96 N. Y. 248; Rhaz'n v. Picrce, I10, Ill. 350; Paine v. Lcstcr, 44 Conn. 196; Catlin v. Wilcox Silver Plate Co., 123 Ind. 477; Linville v. Hadden, 88 Md. 594; Manlattan Co. v. Maryland Steel Co., 3I Western Law Bull. I00; Boston Iron Co. v. Boston Locomotive IVorks. 51 Me. 585; Lichtenstein-v. Gillett, 37 La. Ann. 522; Sands v. Greeley, 88 Fed. I30. The states which favor the receiver are: Gilman v. Ketcham, 84 Wis. 60 ; Bagby v. Atlantic, Miss. E Ohio R., 86 Pa. 291; Long v. Girdicnod, 150 
By putting foreign creditors who invoke the aid of foreign courts on the plane with home creditors, the barrier for a long way is torn down that formerly protected home creditors from outsiders. But since foreign creditors who seek the aid of foreign courts are in some jurisdictions thus favored, why should they be singled out from all the creditors who are represented by a trustee, assignee or receiver? Is the fact that they pursue such a remedy themselves and at their own expense, instead of permitting the receiver to act for them in common with all other foreign and home creditors, a sufficient reason? The importance, however, of this right to foreign creditors, wherever it exists, has been greatly lessened since the enactment of the national bankruptcy law.

Before bringing his suit, a foreign receiver, like any other, must obtain permission from the court whose assistance is desired. ${ }^{41}$ And when granted he cannot sue in his own name on a claim of the corporation, unless he is actually or virtually an assignee of the claim he seeks to enforce. Therefore, in such an action, if the answer is a general denial, the burden is on the plaintiff to show that he is a receiver authorized to bring an action in the foreign courts in his own name, and, in order to recover, must prove that the defendant is liable to him as receiver in the present form of action. ${ }^{2}$

Pa. 413; Robertson v. Staed, I35 Mo. 135; Weil v. Bank of Burr Oak, 76 Mo. App. 547, 27 L. R. A. 324; Sercomb v. Catlin, I28 Ill. 556; Merchants' National Bank v. Pennsylvania Steel Co., 57 N. J. Law, 336; Bentley v. Whittimore, 4 C. E. Green, 462, 469 ; Thurston v. Rosenfeld, 42 Mo. 474.

${ }^{11}$ See Kronberg v. Elder, $18 \mathrm{Kan}$. 150, and Fowler v. Osgood, $72 \mathrm{C}$. C. A. 276. In Avery v. Boston Safe Deposit and Trust Co., 72 Fed. 700, 7or, Putnam, Cir. J. said: "No one can maintain a suit at common law for this indebtedness unless the plaintiff can do it. He is styled a receiver, but he is in substance a trustee, appointed by the statutes and the courts to collect and distribute the assets of the corporation, and vested with the title to them. He is the successor of the corporation, so far as the statutes and the courts can make him such. If he were a mere receiver, in the ordinary sense of the word, the corporation would survive and he could sue in a common law court only in its name. This distinction must be kept in view, and was elaborately expounded in Booth $v$. Clark, i7 How. 322. The plaintiff resembles, in some respects, a new corporation into which an old one has been merged. In Relfe $v$. Rundle, ro3 U. S. 222,225 , a receiver of the same character was described as the successor of the corporation, and it was there said that he was the corporation itself, for all the purposes of winding up its affairs."

12 Homer v. Barr Pumping Engine Co., 180 Mass. 163, citing Amy v. 
If a stockholder is liable for a portion of his umpaid subscription after the failure of the corporation, the receiver is permitted in almost every state in the Union to receive either the entire balance, or the amount needful to pay the corporation's indebtedness. ${ }^{43}$ Only in two or three states, perhaps, does the old doctrine survive, that comity will not permit a foreign receiver tc sue for an unpaid subscription." Even in these the stockholder cannot escape, for a bill in equity will lie against him brought by a creditor for the benefit of all the creditors. ${ }^{45}$

A severe battle has been waged to establish the authority of a foreign receiver to recover the "double liability," thus generally called, of a shareholder, that is, his liability for a sum in addition to the sum subscribed, if needed to pay the indebtedness of the corporation whenever it passes into insolvency. Three rules have been applied in different jurisdictions to those who have sought to recover this contingent fund:

(I) The first and leading view is that the receiver can enforce this liability, with some limitations that will be hereafter considered. Some jurisdictions withhold permission for the reason that, as the sum recoverable is an asset for the direct benefit of the creditors, they only can enforce the remedy. Such jurisdictions readily permit a receiver to sue for unpaid subscriptions, because these are due directly to the corporation he represents. The reason for the distinction is easily seen, but the hollowness of the reason is becoming more and more manifest. While a corporation is a going concern, the creditors have no lien on its stockholders even for their unpaid subscriptions; their sole debtor is the corporation itself; but when a corporation fails, then its entire capital is transformed into a fund for the benefit of its creditors on which they can rely for payment. ${ }^{48}$ The unpaid

Manning, 49 Mass. 487; Wilson v. Welch, 157 Mass. 77; Buszuell v. Order of the Iron Hall, I6r Mass. 224; Fort Payne Coal \& Iron Co. v. Webster, 163 Mass. 134; Ewing v. King, I75 Mass. 570; Hayzeard v. Lecson, 176 Mass. 325.

13 Stoddard $v$. Lum, 159 N. Y. 265; Dayton v. Borst, 3I N. Y. 435; Fish v. Smith, 73 Conn. 377; Manu v. Cooke, 20 Conn. 178; Castleman v. Templeman, 87 Md. 586; Otter Vicz Land Co. v. Bolling, 7o S. W. (Ky.) 8.34; Wyman v. Bowman, 127 Fed. 257.

14 Wyman v. Eaton, 107 Ia. 2I4; Fitzgerald v. Fitzgcrald Construction Co., 4I Neb. 374, 407; Reed v. Burg, 2 Neb. (Unof.) II7.

15 Reed ข. Burg, 2 Neb. (Un. of.) II7.

16 See the often-quoted statement of Justice Brewer in Itollins $v$. Bricrficld Coal \& Iron Co., 150 U. S. 371, 383, 385 . 
capital, therefore, of a corporation before its failure, is not a fund directly belonging to the creditors; only after failure does such a fund become available to them to discharge their indebtedness. As the sum received from both sources, for unpaid stock and the aclditional liability comes from the same persons and is paid the same creditors, there is no good reason why the receiver should not be permitted to ste for it in the one case as well as in the other. And this view is rapidly growing; the substance of things is driving ont the shadow. ${ }^{47}$

If this be the newer and better stustained view, two other views must be mentioned for their force is not yet spent. One is, this liability is a direct asset for the creditors, therefore they must all unite in an equitable suit for their common benefit; or one or more for the benefit of all. This view still prevails in several states. ${ }^{48}$

The third view is that a single creditor can sue a single stockholder, if he likes, to recover the sum due him from the failed institution after he has established his claim against it by suit and judgment. $^{49}$ If the single stockholder is required to pay $\mathrm{it}$, he,

47 Wilson v. Booth, I3 Wash. 676; Watterson v. Masterson, 15 Wash. $5 \mathrm{II}$; Childs v. Cleaves, $95 \mathrm{Me}$ 498; Hale v. Cushman, $96 \mathrm{Me}$. I48; Lanigan v. North, 69 Ark. 62; How'arth v. Lombard, 175 Mass. 570; King v. Vinal, I75 Mass. 580; Broadzuay National Bank v. Baker, 176 Mass. 294; Hancock National Bank v. Ellis, 172 Mass. 39; Love v. Pusey, 3 Penn. (Del.) 577 ; Cushing v. Perot, I75 Pa. 66; Howarth v. Angle, 162 N. Y. 179; King v. Cochran, 72 Vt. 107; Kirtley v. Holnes, 107 Fed. 747; Sheofe v. Larimer, 79 Fed. 921 and cases cited; Cuykendall v. Miles, ro Fed. 342. See Castleman v. Templeman, 87 Md. 546, and Whitman v. Oxford National Bank, 176 U. S. 559. In Wigton v. Bosler, 102 Fed. 70, a receiver of an Iowa bank was not permitted to sue a stockholder in Pennsylvania as an act of comity. It might have been shown that, at that time in Iowa, a stockholder was liable only by suit of the creditors. See Wyman $v$. Eastern, 107 Ia. 214.

${ }^{48}$ Western National Bank v. Lazurence, II7 Mich. 669. 673; Guerncy v. Moore, 13I Mo. 650; Pfaff v. Gruen, 92 Mo. App. 560, containing an elaborate review of cases; Morris v. Glenn, 87 Ala. 628; Ferguson v. Sherman, r16 Cal. I69; Abbott v. Goodall, I00 Me. 23I; Bcll v. Farwell, 176 Ill. 489; First National Bank v. Gustin Mining Co., 42 Minn. 327; Woodwarth v. Bozules, 6I Kan. 569, 582; Rhodes v. United States National Bank 66 Fed. 512; McVickar v. Jones, 70 Fed. 574; Bank of North America v. Rindge, 57 Fed. 279; Stalc National Bank v. Sayzurd, 97 Fed. 443; Relfe v. Rundle, 103 U. S. 222; Flasit v. Conn., I09 U. S. 371; Huntington v. Atrill, 146 U. S. 657; IWhitman v. Oxford National $B a n k$, I76 U. S. 559.

${ }^{49}$ Ferguson v. Sherman, I16 Cal. 169; Pulsifer v. Greene, 96 Me. 438; 
in turn, can sue his co-stockholders for their just contributions. ${ }^{.0}$ The second and third view is opposed to the view first mentioned on the ground that the liability "is created directly to the creditors and cannot be enforced by receivers in their own names or in the name of the corporation." si

There are cogent reasons for not adopting this third view. The foreign stockholder, wherever this remedy exists, may be required to pay more than the home stockholler. "Nothing," remarks the Supreme Court of Rhode Island, "could be more unjust than to permit a creditor or a number of creditors to recover from a foreign stockholder to the full amount of his liability, when other stockholders residing in the home state were only required to contribute a less proportion of the value of their stock." 52 To throw on a stockholder who has thus paid more than his fair share toward discharging the indebtedness of the insolvent corporation the trouble and expense of suing his associates for contributions, is a great hardship.

By permitting the receiver to sue, all danger of unequal assessments or demands of stockholders is avoided and the procedure is reduced to the lowest terms and figures. Says Mr. Justice Mitchell: "A receiver represents not only the corporation but all its creditors, and as to the latter, it is his cluty to secure all the assets available for their payment. For this purpose, he succeeds to their rights and has all the powers to enforce such rights that Gucrncy 2. Moorc, I31 Mo. 650; Lanigan v. North, 69 Ark. 62, 65; Hancock National Bank v. Ellis, 166 Mass. 414; Bank of North America $v$. Rindge, 57 Fed. 279; Mechanics' Savings Bank v. Fidelity Trust and Safe Deposit Co., 87 Fed Ir3.

so See Hancock National Bank v. Ellis, 172 Mass. 39, 48.

${ }^{51}$ Hancock National Bank v. Ellis, I72 Mass. 39, 49, citing Ibid; 166 Mass. 4I4, 419; National Bank of Barre v. Hingham Manufacturing Co., 127 Mass. 563, 567; Chamberlin v. Hugenot Manufacturing Co., II8 Mass. 532.

52 Miller v. Smith, 26 R. I. 146, 15I. In answer to this, Powers, J., speaking for the Supreme Court of Maine in the case of a stockholder in a Kansas bank, who had been sued in Maine by a foreign creditor, said: "The defendant has the same right to enforce contribution as he would have if he resided in Kansas. It is the remedy which he accepted, when, for purposes of gain he voluntarily accepted his stock, knowing that the law placed upon him, and not upon the creditor, the burden of enforcing contribution among the stockholders. $\mathrm{He}$ is simply held to the contribution which he made, and by which he agreed with the corporation creditor to become responsible to him, severally and individually, and not jointly or ratably." Pulsifer v. Grecnc, $96 \mathrm{Me} .438,474$. 
the creditors before his appointment had in their own behalf, even though such powers be beyond those which he has as the representative of the corporation alone. As each creditor may sue, the right is equal in all, and common to all, and hence the receiver who represents all alike is the proper party to assert the common right and pursue the common remedy, for the common benefit. In this manner the rights of all will be protected and justice be done in a single proceeding in which everyone will get what is his due, no one will be called upon to pay more than his fair proportion, and the expense, delay, inconvenience and inevitable occasional injustice of separate actions by different creditors against different stockholders, with their attendant legion of resulting actions for contribution will be avoided." ss

This is the practice under the national banking law, and its efficiency and economy are so manifest that no opposing criticism is ever heard. The federal courts, too, do not hesitate to recognize foreign receivers in such cases, because their authority is founded on statute and their recognition does not in any way conflict with the practice of federal tribunals with respect to chancery receivers. Of course, a foreign receiver cannot maintain his suit if there be any doubt concerning the validity of the assignment or power from which he derives his authority ; the deficit required of stockholders has not been determined by a court of proper authority. ${ }^{55}$

Since, however, receivers both at home and abroad proceed against stockholders only after the amount of their liability has been transformed into assessments against them, courts are showing an increasing inclination to regard the proceedings establishing the liability of stockholders as less conclusive than formerly. Always, the judgment forming the basis of this liability has been impeachable for fraud; now, the judgment forming the basis of action against stockholders can be attacked for mistake, ${ }^{58}$ for lack of jurisdiction, ${ }^{87}$ and in some states $^{58}$ for non-notification

${ }^{53}$ Cushing v. Perot, $175 \mathrm{~Pa} .66 ;$ Bates v. Day, $198 \mathrm{~Pa} .513$, overruling in effect. Aultman's Appeal, $98 \mathrm{~Pa} .505$.

54 Connor v. Omaha National Bank, 42 Neb. 602.

${ }^{50}$ McLaughlin v. O'Neill, $7 \mathrm{Wy} .187$ and 215; Clark v. Knozvles, 187 Mass. 35; Wigton v. Bosler, I02 Fed. 70.

56 Merchants' Bank v. Chandler, 19 Wis 434.

67 Ball v. Reese, 58 Kan. 614; Fogg v. Ellis, 6I Neb. 859. Scherts v. First National Bank, 47 111. App. 124; American National Bank v. Supplee, Ir5 Fed. 65\%. 
of foreign stockholders of the action in which judgment was obtained against their corporations. On the one hand, while courts are more disposed to permit foreign receivers to sue non-resident stockholders for their liability, onthe other hand, courts are more and more disposed to regard the preliminary proceedings as possessing only a prima facie instead of a conclusive character, thus protecting them fully in the end from unjust judgments and excessive payments.

Two other important principles are also applied in all proceedings by foreign receivers. No state will permit a foreign receiver to sue within its jurisdiction who derives his authority from the court or statute of another state that withholds similar authority to foreign receivers. The permission is based on comity, and is given only where comity prevails. ${ }^{58}$

The other principle is, a foreign receiver may pursue a foreign stockholder in his own state provided such action be not contrary to its policy. Indeed, in some states, the double liability may be enforced by comity against its citizens even though this principle has not been adopted and applied to them as members of their own home corporations. ${ }^{80}$ Nor is there anything unreasonable or illogical in this extension of the doctrine. For, we should remember, the liability rests on a contract into which a stockholder voluntarily enters, and from which he derives solid advantages. If such a contract were forbidden by the state in which the foreign stockholder lives, then indeed the courts in that state might with good reason decline to enforce it. But the mere fact that such a contract is not made and therefore does not exist, in a foreign state, is no proof that it is unlawful and ought not to be enforced. Doubtless, there are contracts made in every state that are peculiar, growing out of local customs, methods, and kinds of business which are enforced in other jurisdictions. Nevertheless, as most of the states have adopted and applied the principle of double liability to the members of some or many of the corporations they have created, and the worth of the principle

58 Farmers' Loan and Trust Co. v. Funk, 49 Neb. 353; Wheatley v. Glover, I25 Ga. 7ro.

${ }^{5}$ Childs v. Cleaves, 95 Me. 498; Howarth v. Lombard, I75 Mass. 570; Howarth v. Angle, 162 N. Y. 179; Love v. Pusey, 3 Penn. 577; Wyman v. Kimberly-Clarke Co.; 93 Wis. 554, 559; Russell v. Pacific Railway Co., I13 Cal. 258; Finney v. Guy, I89 U. S. 335.

${ }^{\circ 0}$ Guerney v. Moore, 131 Mo. 650, 673. See Childs v. Cleaves, $95 \mathrm{Me}$. 509 . 
is growing in judicial and popular favor, the non-existence of the principle in any state is scant reason for refusing to enforce a contract on proper occasion against one of its citizens who has made such a contract in another state.

Another difficulty has sometimes been experienced by receivers. If the law prescribing the liability of stockholders also prescribes the remedy, then, it has been said, as the home remedy cannot be enforced in the foreign state, the receiver has no standing in its courts. ${ }^{81}$ Wherever the doctrine has been held in this rigid form, it has meant a denial of justice to creditors and a complete shield to foreign stockholders, for they were not likely to visit intentionally the home state where the specific remedy could be enforced for the purpose of submitting to its tribunals. "It certainly concerns the due administration of justice," remarks Chief Justice Field, "that all stockholders, wherever they reside, should be compelled by proceedings somewhere to perform the statutory obligations towards creditors of the corporation which they have assumed by becoming stockholders." ${ }^{22}$ How, then, have the courts dealt with this matter? In at least three ways. If the law creating the stockholder's obligation has prescribed no remedy, then the foreign state has applied its own remedy, and compelled the stockholder living there to fulfil his obligation. ${ }^{63}$

In the second class of cases the courts, regarding the liability of stockholders as essentially contractual and not statutory, have enforced it without regard to the remedy prescribed by the home power. This is the modern view which prevails almost everywhere. ${ }^{*}$ Rather than cut one off from redress where the foreign remedy "is the only means of enforcing an undoubted right." contended Chief Justice Ewing, sixty years ago, in the moclern

11 See Hondarth v. Angle, 162 N. Y. 179, 188; Barnes v. Wheaton, 80 Hun. 8 ; Nimick v. Mingo Iron Works, 25 W. Va. 184 ; Hancock National Bank v. Ellis, 172 Mass. 39 and cases cited; Finney.v. Guy, 106 Wis. 256; Abbott v. Goodall, 100 Me. 23I; Middletown National Bank v. Toledo and Northern Michigan R., 197 U. S. 394 and cases cited.

22 Hancock National Bank v. Ellis, 172 Mass. 39, 47; Childs v. Clcaves, 95 Me. 498, 516; Boll v. Farzuell, I76 Ill. 489.

${ }^{\circ 3}$ Russell v. Pacific Railway Co., Ir3 Cal. 258, 26r.

64 Howarth v. Angle, 762 N. Y. 179; Howarth v. Lombard, 175 Mass. 570; Broadcuay National Bank v. Baker, 176 Mass. 294; Cushing v. Perot, $175 \mathrm{~Pa} .66$; Wilson v. Book, 13 Wash. 511; Childs v. Cleaves, 95 Me. 498; Pulsifer v. Greene, 96 Me. 438, 445, 446; Love v. Pusey, 3 Penn. 577; Lanigan v. North, 69 Ark. 62 ; Kirtley v. Holmes, 107 Fed. I. See Whitman v. Oxford National Bank, I76 U. S. 559. 
spirit, "the principle of comity ought to be so far extended as to permit him to use the foreign remedy." ${ }^{\circ 5}$ And Justice Vann of the New York Court of Appeals, recently, while asserting the existence of the distinction above mentioned, reasoned as though, for the higher end of justice, it ought to be disregarded. "It is not necessary," said the Justice, "that the procedure to enforce the liability in question should be that required by statute in this state in the case of domestic corporations, as that would frequently be impossible and would withhold the rights of comity altogether. It is sufficient if the method of procedure in our courts is such that no injustice is done to the stockholder who is sued, or to any citizen of this state, and the established policy of the state is not interfered with." 86

But not in every state. In one at least when the liability and remedy are prescribed by the same statute, the remedy is still regarded as exclusive, which cannot be enforced in another state where the foreign stockholder lives, thus enabling him by using the thin theoretic veil of the law to escape from executing his just obligation. This is the Wisconsin way of looking at the matter. ${ }^{67}$ But not by all the members of its court of last resort. In a recent decision, in which this exclusive remedy theory was maintained, Justice Dodge, in a dissenting opinion, ringing with sense and justice, declared that the decision destroyed a clear and absolute right by denying any remedy for its enforcement, and that, too, for no better reason than mere inconvenience to courts in their procedure; an inconvenience, too, which seemed to him "rather imaginary than real. This is a result which is not to the credit of the courts," ${ }^{88}$ - a conclusion which none, save the reverential upholder of technicalties will question.

\section{Albert S. Bolles}

${ }^{63}$ Bank v. Trimble, 6 B. Mon. (Ky.) 599, 604, dissenting opinion.

${ }^{\text {Be Howarth }}$ v. Angle, I62 N. Y. 190, 191.

${ }^{67}$ Finney v. Guy, 106 Wis. 277. See May v. Black, 17 Wis. ror review of cases.

GR Ili:d. 